\title{
BOALA DE FOCAR AMIGDALIANĂ
}

\section{Cornean-Santa Corina', Cornean Corina lulia ${ }^{2}$}

${ }^{1}$ Spitalul Județean de Urgență Satu Mare, medic primar ORL, doctor în medicină

${ }^{2}$ U.M.F. "Iuliu Hațieganu" Cluj-Napoca, student

Amigdalele palatine ocupă lojile amigdaliene, care la rândul lor formează peretele lateral al bucofaringelui. Ele sunt două formațiuni limfoide, care fac parte din cercul limfatic faringian Waldeyer (Pirogov). Amigdalele palatine se găsesc la majoritatea mamiferelor, sub diferite mărimi.

Fiecare amigdală are forma unui ovoid asezat în loja amigdaliană. Faţa internă mediană, este acoperită de mucoasa faringiană și prezintă un număr de 18-22 orificii, care reprezintă deschiderea criptelor amigdaliene. La nivelul polului superior se găsește cripta magma, cea mai mare dintre acestea. Epiteliul care acoperă partea liberă a amigdalei pătrunde și în criptă. La acest nivel poate staționa cazeumul, ce apare ca niște grunji albicioși de consistență dură și care dau miros neplăcut gurii (fiind format din celule descuamate, leucocite dezintegrate, particule alimentare, microbi saprofiți ai cavității bucale, produse de distrucție tisulară).

Fața externă sau laterală, aplicată pe peretele lateral al faringelui, este acoperită de un țesut fibros, ce reprezintă o condensare a țesutului celular lax de la acest nivel și care formează capsula amigdaliană. Capsula trimite în corpul amigdalian prelungiri fibroase, care o împart în lobi limfatici. Fiecare lob este alcătuit dintr-o criptă centrală și un schelet fibros, între care se află corpusculii limfatici. Lobii, care au o stuctură identică cu cea a ganglionilor limfatici, sunt acoperiți de un epiteliu stratificat pavimentos, o continuare a mucoasei buco-faringiene. Foliculul limfatic are o structură rotundă, cu două zone: una periferică închisă și o a doua centrală, mai clară, cunoscută sub denumirea de centru germinativ, în care se formează leucocite mononucleare.

Infecțiile țesutului limfoid faringian (și în special cel amigdalian) nu rămân întotdeauna izolate la nivelul faringelui, ci pot să dea o serie de complicații în întregul organism. Infecția de focar faringiană poate fi rezultatul infecțiilor de la nivelul amigdalelor sau dinților.

Teoria infecției de focar a fost introdusă în patologie de Billings în 1912. Interesul s-a concentrat asupra acestei afecțiuni deoarece focarul amigdalian reprezintă una dintre cele mai frecvente infecții din organism, iar, pe de altă parte, pentru că principalele consecințe ale acesteia asupra organismului (respectiv afecțiunile cardiace, renale și reumatismele) ocupă un loc important în patologia generală.

Elementul determinant în transformarea unei infecții oarecare într-o infecție de focar este închistarea cu lipsa posibilității de drenaj, transformarea ei într-o infecție cronicizată și circumscrisă. Tesuturile din jurul acelui focar realizează un proces de delimitare, o barieră morfologică (mecanică), formată din țesut de granulație, vase sanguine de neoformație și leucocite. La această barieră mecanică se adaugă și o barieră morfochimică prin imunizarea țesuturilor învecinate (proces de aparare imunologică).

De-a lungul timpului au fost emise mai multe explicații pentru a interpreta răsunetul și modificările la distanță pe care le produce infecția de focar în organism:

- acțiunea directă a toxinelor microbiene (teoria toxică)

- acțiunea la distanță prin mecanism alergic

- acțiunea distrofică prin mecanism reflex. 
Studiile moderne de histochimie au demonstrat faptul că infecția de focar amigdaliană acționează prin mecanism alergic de autoagresiune. Studiile microscopice efectuate pe țesuturile din jurul criptelor amigdaliene au arătat prezența unor zone de necroză, localizate în spațiile dintre formațiunile foliculare limfoide, și care sunt alcătuite din foarte multe limfocite mari și plasmocite. Aceste structuri histologice sintetizează activ imunoglobuline, ceea ce indică și o agresiune umorală. De asemenea, în zonele respective se evidențiază și o acțiune citotoxică, cu participarea complementului.

Până în prezent nu a fost identificat un antigen specific în amigdalita cronică, dar mecanismul de tip Antigen-Anticorp (Ag-Ac) de apărare, care poate produce determinările la distanță, poate fi comparat cu cel de autoîntreținere din colagenoze.

Enzimele bacteriene din focarul amigdalian pot transforma prin acțiune citoproteinotoxică unele structuri locale în autoantigeni. Aceștia, prin eliminare continuă, autoîntrețin suferința amigdaliană. Agresiunea se poate extinde și la nivelul organismului, unde Ag determină reacții umorale sau tisulare patologice.

Amigdala cronic infectată poate suferi în timp reacții de metaplazie conjunctivă, care modifică structura primară a amigdalei, fără a stinge complet procesul infiltrativ de autoagresiune, care se menține.

Efectul la distanță al focarului se manifestă prin mecanism toxico-alergic de autoagresiune, în care intervin Ac, limfocite, macrofage, etc.

După Coomb (1979), reacțiile organismului la agresiunea unui antigen pot fi imediate (hiperergice), sau se pot produce lent (de tip întârziat), la care participă de regulă limfociții. În esență, reacțiile întârziate reprezintă modul de instalare a sensibilității în contextul focarului de infecție cronică amigdaliană.

Din cele cinci tipuri de reacții hiperergice cunoscute, trei intervin cu certitudine în mecanismele ce determină consecințele la distanță ale suferinței cronice amigdaliene:

1. Reacția hiperergică de tip citotoxic

Se caracterizează prin prezența în sânge a unor mase de molecule proteice, asemănătoare cu Ig G sau Ig M. Acestea acționează ca anticorpi față de unele formațiuni celulare non-self din sângele și umorile organismului. Mecanismul de acțiune al citotoxicității este reprezentat de activarea complementului și nu sensibilizarea pentru complexele imune. Efectul distructiv este foarte mare când celula țintă este liberă, sau este un endoteliu vascular. Mecanismul este propriu pentru nefritele autoimune.

2. Reacția mediată de complexe imunotoxice

Antigenul este o substanță solubilă care se găsește în sânge sau umori și determină apariția de anticorpi specifici, cu formare de complexe Ag-Ac, cu acțiune toxică asupra organismului. Aceste complexe activează complementul și au capacitatea de a se fixa în pereții capilarelor și arteriolelor, unde produc distrucții.

3. Reacția de tip întârziat se realizează prin intermediul limfocitelor T, care trebuie sensibilizate în prealabil (faza de inducere). Odată sensibilizat, limfocitul T și descendenții lui păstrează memoria imonologică a acestei acțiuni, iar la o nouă agresiune a Ag, răspunde prin inducerea unor fenomene de tip întârziat.

În concluzie, dacă intensitatea agresiunii este mică, predomină rolul de apărare al amigdalei, cu distrugerea Ag. Dacă agresiunea este intensă și repetată, se produc efecte distructive asupra structurilor organismului.

Rolul biologic al unei amigdale normale este cel de apărare. Celulele imunocompetente din structura amigdalei normale, sănătoase, au rol fiziologic imunoreactiv, însă în condițiile unor inflamații repetate, acest rol poate evolua spre autoagresiune.

Răspunsul organismului la fenomenele de autoagresiune declanșate de focarul infecțios poate fi apreciat imunobiologic prin testul ASLO, dozarea Ac, antiproteina $\mathbf{M}$, a crioproteinelor, imunoglobulinelor serice, a complementului seric, a PCR și a factorului reumatoid. În funcție de gradul lor de modificare, putem să stabilim momentul intervenției chirurugicale, oferind posibilitatea instituirii unei terapii corecte și eficiente, precum și controlul în timp al eficienței tratamentului. 


\section{Concluzii}

1. Focarul amigdalian reprezintă unul din cele mai frecvente infecții de focar din organism.

2. Consecințele acestuia și anume afectarea cardiovasculară, renală sau reumatismele, ocupă un loc important în patologia generală.

3. Elementul determinant în transformarea unei infecții oarecare într-o infecție de focar este dată de posibilitatea de închistare și lipsa posibilităţii de drenaj.

4. Focarul de infecție amigdaliană acționează asupra organismului prin mecanism alergic de autoagresiune.

5. Reacțiile alergice de tip întârziat reprezintă modul de instalare a sensibilității în contextul infecției de focar amigdaliană.

6. Rolul fiziologic al unei amigdale normale este cel de apărare.

7. În condițiile unor infecții recurente, prelungite, acest rol inițial benefic poate vira spre fenomene de autoagresiune, cu afectarea la distanță a organismului.

\section{Referințe}

1. Dejica D. Tratat de Imunoterapie, Cluj-Napoca, ed.Mega, 2006.

2. Geormaneanu M., Gherghina I. Imunitatea si bolile immune la copil. Bucureşti, ed.Medicală, 1983.

3. Costinescu N. Garbea S, Popovici G, Racoveanu V, Tetu I. Oto-Rino-Laringologie. Bucureşti, ed.Medicală, 1964.

4. Sarafoleanu D, Sarafoleanu C. Compendiu de O.R.L. Bucureşti, ed.Naţional,1997 